\title{
District magnitude and representation of the majority's preferences: Evidence from popular and parliamentary votes
}

\author{
Marco Portmann • David Stadelmann • \\ Reiner Eichenberger
}

Received: 20 July 2010 / Accepted: 22 December 2010 / Published online: 14 January 2011

(C) Springer Science+Business Media, LLC 2011

\begin{abstract}
Representatives have more effective incentives to cater to the preferences of the majority of citizens when they are elected in districts with few rather than many seats. We investigate this hypothesis empirically by matching Swiss members of parliament's voting behavior on legislative proposals with real referendum outcomes on the same issues for the years 1996 to 2008. We thus identify the impact of district magnitude on representatives' incentives to adhere to citizens' revealed preferences. We find systematic, statistically significant and economically relevant evidence that individual representatives from districts with few seats vote more often in line with majority preferences.
\end{abstract}

Keywords Voter preferences $\cdot$ Political economy $\cdot$ Electoral systems

JEL Classification D72 $\cdot$ D70 $\cdot$ H00

\section{Introduction}

The influence of electoral systems on policy outcomes is not only at the center of the public debate on policy reforms but it also increasingly attracts the interest of economists (see Grossman and Helpman 2005; Milesi-Ferretti et al. 2002; Persson et al. 2007). A main focus of analysis is district size and how it aligns the behavior of representatives with citizens' preferences. From a theoretical perspective, district magnitude, i.e., a district's number of

M. Portmann · D. Stadelmann $(\bowtie) \cdot R$. Eichenberger Department of Economics, University of Fribourg, Bd. de Pérolles 90, 1700 Fribourg, Switzerland e-mail: david.stadelmann@unifr.ch

M. Portmann

e-mail: marco.portmann@unifr.ch

R. Eichenberger

e-mail: reiner.eichenberger@unifr.ch

D. Stadelmann $\cdot$ R. Eichenberger

CREMA - Center for Research in Economics, Management and the Arts, 4052 Basel, Switzerland 
seats in parliament, determines incentives for representatives. Members of parliament from districts with many seats and proportional representation may win elections by proposing policies for groups at the boundaries of the electoral spectrum. Conversely, members of parliament from districts with a limited number of seats or close to plurality systems are supposed to propose platforms closer to the majority's interests (see Gagliarducci et al. 2008). Moreover, for members of parliament from districts with many seats, representation of their voters' interests may become a public good, while members of parliament from districts with fewer seats may have to take personal accountability for their decisions (see Lizzeri and Persico 2001). Thus, moving from a few seats towards a proportional system induces individual members of parliament to diverge more from the majority's will.

However, the clarity of the theoretical reasoning contrasts with the lack of empirical evidence. To date, no study has analyzed the influence of electoral systems on the behavior of representatives by directly comparing their behavior with revealed voters' preferences on exactly the same issues.

In this paper we analyze how the number of representatives per district influences, $c e$ teris paribus, the incentives of individual members of parliament to vote according to the preferences of the majority of the citizens. Switzerland offers a unique quasi-experimental setting to analyze the incentives of politicians to act according to the will of the majority: The electoral districts for national parliamentary elections coincide with the Cantons, i.e., the Swiss states. District magnitudes, i.e., the number of seats per district, differ largely, ranging from small districts with one seat and pure plurality rule to large districts with 34 seats and proportional representation. Thus, in the Swiss electoral system, a change from one seat to many seats also reflects a change from pure plurality to proportional representation. Similar to other democratic countries, members of the Swiss national parliament vote on new laws and law changes as well as constitutional amendments. But, in contrast to other countries, a relatively small number of Swiss citizens (50000 from a total population of almost eight million) can demand a popular referendum on parliamentary decisions before laws are enacted. In addition to parliamentary amendments, a group of citizens (100000) can also start an initiative and demand a constitutional amendment. Members of parliament then have to express their opinion on the proposed amendments before the population votes on them. In these popular votes, citizens reveal their preferences for policy outcomes by ranking law proposals against the status quo (see, e.g., Schneider et al. 1981; Cronin 1989; Matsusaka 1992; Frey 1994; Besley and Coate 2008).

This setting makes Switzerland an ideal field to study the influence of district magnitude on the relationship between voters and their representatives. Thus, we match Swiss referendums data with voting data from individual members of parliament on exactly the same political issues with the same wording. This allows us to identify empirically whether members of parliament from large districts with proportional representation diverge more from the preferences of the majority of the voters than politicians from small districts. To the best of our knowledge, no previous research has matched revealed voter preferences from referendums with real policy decisions in parliament and analyzed the effects of district size on divergence between voters and members of parliament. We directly identify two variables which indicate whether members of parliament have voted in accordance with the majority of voters at the district level as well as at the national level. These two dependent variables are explained by the number of seats in parliament, i.e., the electoral system, of a district. Empirical results indicate that decisions of members of parliament from districts with a large number of seats and proportional representation diverge, ceteris paribus, more from the majority of constituents as well as from the national majority's preferences. Plurality rule, as measured by a low number of seats, tends to align decisions of members of 
parliament with district voters' preferences as well as national voters' preferences. These results are highly robust when we control for a large number of variables which may induce deviations between members of parliament and voters' preferences, e.g., party positions, individual characteristics of parliamentarians, and district characteristics.

As an important advantage, our research focuses on differences within a single country. Thus, it avoids problems common to cross-country research: When analyzing political decisions and preferences across countries, specific norms, rules, political patterns, history, culture and institutional contexts should be taken into account. In our case the sub-national electoral districts provide a broad empirical field within a common framework of identical basic characteristics.

The remainder of this paper is organized as follows: Sect. 2 provides a brief literature review, theoretical considerations and additional explanations of the electoral system's effects on voting behavior of members of parliament. Section 3 presents the data, the econometric approach as well as a short overview on the Swiss political system and the role of referendums. Empirical results for all members of parliament in 102 national referendums over the years 1996 to 2008 are presented in Sect. 4. The econometric robustness of our hypotheses is extensively tested considering differential hypotheses and using Bayesian Model Averaging to investigate the effect of variable selection. Finally, Sect. 5 offers some concluding remarks.

\section{Literature and theory}

\subsection{Literature overview}

Starting with Duverger (1954) and Downs (1957), large parts of the theoretical literature have focused on the electoral systems' influence on the number of political parties and their positions. "Duverger's Law" and its modifications usually predict the emergence of and two-party competition in districts with plurality rule. Downs (1957) first described what positions political candidates would take when competing for a seat in a small district with one seat only. The well-known result in a Downsian world is convergence to the median voter's position. Thus, the early literature argues that electoral competition in small districts concentrates on winning the majority as only few persons can gain seats in the district (for more recent contributions see, among others, Cox 1997; Persson and Tabellini 2002, 2005; Lizzeri and Persico 2001).

In contrast, proportional representation in districts with many seats induces multi-party competition, and parties are expected to take more dispersed positions in multi-member districts as argued by Cox (1990). Generally speaking, in a system of proportional representation electoral competition is spread over the whole political spectrum as the median voter loses part of its importance (see, e.g., Taagepera and Shugart 1989). But of course, there are also mechanisms which may induce diffused political positions under plurality rule (see Cox 1997). For instance, Bordignon and Tabellini (2010) show that under dual ballot (where citizens select a subset of candidates in a first round and cast a final vote in a second round) the number of political positions increases. However, plurality with a dual ballot may reduce the influence of extremist voters on equilibrium policy outcomes under sincere voting because dual ballot reduces the bargaining power of extremist parties.

Political representation has certain characteristics of a public good. Lancaster (1986) argues that regional representation is a public good for members of parliament from districts with many seats. If many members of parliament claim responsibility for a certain policy 
with local ramifications, each individual deputy's incentives to provide good representation may decrease. Hence, the link between representatives and their constituencies is strongest in plurality or close to plurality systems with few seats.

There is a growing empirical literature analyzing the effects of district magnitude, i.e., proportional representation, on party positions. For instance, Dow (2001) finds differences in the extent of spatial dispersion among parties and candidates between plurality and proportional electoral systems when comparing data from election studies and surveys for Canada, Israel, the Netherlands and France. In systems with small districts, parties and candidates are located significantly closer to the majority within the distribution of voters than their counterparts in proportional systems.

Members of parliament may also face several competing principals and competing interests when representing voters' interests according to empirical studies by Carey (2007) or Braendle and Stutzer (2010). Party affiliations, interest groups, personal linkages and heterogeneity play a role apart from the electoral system. Crisp et al. (2004) argue empirically with data of bill initiation activity in six presidential democracies that with centralized candidate selection and as district magnitude increases, members of parliament will less frequently initiate legislation aimed at a particular constituency and rather focus on the national party's interest. By analyzing voting results of two different amendments enacted by the Swiss parliament and surveys conducted amongst the legislators, Bailer et al. (2008) find that deputies elected under proportional representation, i.e., from districts with a larger number of seats, act closer in accordance with their parties than deputies from small plurality or close to plurality districts. Thus, district magnitude influences members of parliament through their party affiliations.

Policy outcomes have recently started to attract the interest of political economists (see Grossman and Helpman 2005). When focusing on individual or group welfare, researchers predominantly captured policy outcomes by fiscal policy measures. Persson and Tabellini (1999) as well as Milesi-Ferretti et al. (2002) argue that spending on transfers is extended further under proportional electoral systems due to different incentives for redistribution. These authors are mainly concerned with incentives for pork barrels under alternative electoral systems. Milligan and Smart (2005) find for Canada which exhibits a plurality system that governing parties target swing districts. These findings substantiate the hypothesis that plurality systems create a direct incentive for members of parliament to better target the majority of voters with specific policies when the number of seats is small. Conversely, under proportional representation members of parliament may concentrate on different groups over the political spectrum instead of focusing on the majority's preferences.

\subsection{Theoretical considerations}

The question of how different electoral rules shape a nation's political system has received much attention amongst economists and political scientists (for more recent contributions see Lizzeri and Persico 2001; Milesi-Ferretti et al. 2002; Bawn and Thies 2003; or Blume et al. 2009). In contrast, the question of how individual decisions of members of parliament affect voter utility and welfare has received less thought.

The outlined literature identified two main channels for decreasing incentives to respond to the majority's interests in districts with many representatives and proportional representation: First, deputies from districts with a limited number of seats need to propose platforms closer to the center while deputies from districts with many seats may also win elections by proposing policies for groups at the margin. Thus, proportional representation with many seats induces individual members of parliament to cater less for the voter majority. When 
district size decreases, members of parliament need to focus more on the majority's preferences in order to win elections.

Second, we also expect individual members of parliament from smaller district to act more according to the majority's interest because regional representation is a public good. With many members of parliament who claim responsibility for a certain policy with local ramifications, each individual deputy's incentives to provide local representation decrease. Hence the link between members of parliament and citizens preferences is stronger in smaller districts.

All these arguments lead us to the hypothesis that individual members of parliament from districts of small magnitude, i.e. with a low number of seats, represent, ceteris paribus, the majority's preferences better than individual members of parliament from large districts. As district magnitude increases, the Swiss electoral system changes from pure plurality to proportional representation. We are thus able to test our hypothesis.

\section{Data and estimation strategy}

\subsection{Overcoming measurement problems}

Stratmann (1995), Bender and Lott (1996), Gerber and Lewis (2004) and Golder and Stramski (2010) among others argue that a major problem of empirical studies is to determine voters' positions with respect to law proposals and to match them with decisions or positions of members of parliament. Positions of voters and politicians are usually constructed policy dimensions which stem from survey data. Party positions are no measures for policy outcomes. Financial measures allow identifying effects of electoral systems on policy outcomes but they are no sensible measure of the majority's preferences especially when more policy dimensions exist such as equity vs. equality, liberal vs. conservative, etc.

We overcome possible measurement problems by introducing two unique measures for the majority's preferences which are confronted with real policy decisions by members of parliament. In referendums, Swiss citizens regularly cast their votes on law and constitutional proposals which have passed national parliament with exactly the same wording. Referendums results determine policy outcomes and are at the same time the revealed preferences of citizens for these outcomes. More precisely, referendums permit the majority to rank policy outcomes induced by the proposed laws against the status quo. Thereby, decisions in referendums are capable of capturing much broader issues than fiscal policy measures and it is not necessary to rely on expert's judgment or surveys on the utility implications for the majority. The majority's preferences reveal themselves in a referendum.

To evaluate the influence of the number of seats, i.e., the electoral system, in a district on voting with or against the majority of voters, we match data of 102 referendums with information on votes with the same wording of individual members of parliament in Switzerland for the years 1996 to 2008. Thereby, we create a unique dataset where real choices of all legislators on all referendums can be confronted with real choices of voters on exactly the same issues.

The Swiss National Council, i.e., the lower house, has 200 seats. The 26 Swiss cantons (sub-national jurisdictions) form the national parliament's electoral districts. The number of seats for each canton is proportional to the cantons' population sizes. Population size and, thus, the number of seats differ largely between cantons. The six cantons Appenzell a.R., Appenzell i.R., Glarus, Nidwalden, Obwalden, and Uri have only one representative in parliament and exhibit pure plurality systems. 13 electoral districts have between one 
Table 1 Swiss cantons

Notes: The official seat

distribution is calculated based on the 2000 population census. Number of resident permanent population in Switzerland according to census and the districts' number of seats in the National Council after 2003.

Source: Federal Statistical Office

\begin{tabular}{|c|c|c|}
\hline Canton & Population in 1000 & Seats in Council \\
\hline Aargau & 540.639 & 15 \\
\hline Appenzell Ausserrhoden & 53.737 & 1 \\
\hline Appenzell Innerrhoden & 14.946 & 1 \\
\hline Basel-Landschaft & 258.602 & 7 \\
\hline Basel-Stadt & 188.458 & 5 \\
\hline Bern/Berne & 943.427 & 26 \\
\hline Fribourg/Freiburg & 234.307 & 7 \\
\hline Genève & 403.067 & 11 \\
\hline Glarus & 38.708 & 1 \\
\hline Graubünden/Grigioni & 186.026 & 5 \\
\hline Jura & 68.818 & 2 \\
\hline Luzern & 345.357 & 10 \\
\hline Neuchâtel & 165.649 & 5 \\
\hline Nidwalden & 37.657 & 1 \\
\hline Obwalden & 32.225 & 1 \\
\hline Schaffhausen & 73.552 & 2 \\
\hline Schwyz & 128.248 & 4 \\
\hline Solothurn & 243.908 & 7 \\
\hline St. Gallen & 447.609 & 12 \\
\hline Thurgau & 227.285 & 6 \\
\hline Ticino & 308.498 & 8 \\
\hline Uri & 35.487 & 1 \\
\hline Valais/Wallis & 275.632 & 7 \\
\hline Vaud & 616.275 & 18 \\
\hline Zug & 97.758 & 3 \\
\hline Zürich & 1198.569 & 34 \\
\hline Total & 7164.444 & 200 \\
\hline
\end{tabular}

and five members of parliament while the remaining cantons have more than five members of parliament. This large heterogeneity allows us to identify the effect of district size on voting behavior of deputies in parliament under different electoral systems (see Table 1 for an overview over the cantons, with their respective number of seats and their population size).

The National Council has 12 committees, each concerned with a policy area such as foreign affairs, social security, health, etc. These committees formulate the proposals for laws and law changes which are presented to the plenum where all members of parliament decide on them. The parliamentary services record individual votes carried out on legislative proposals for every member of parliament and make them publicly available. A proposal is adopted as new law or as a constitutional amendment if the majorities of both, the National Council and the Council of States (i.e., the upper house or senate), approve it.

However, proposals adopted by parliament do not necessarily turn into law (see, e.g., Kirchgässner et al. 1999; Fossedal 2002). If a legislative proposal aims to change the constitution, a referendum is mandatory. Moreover, for such mandatory referendums a double majority is required: the majority of the national electorate as well as a majority of the elec- 
torate in 11 and a half-canton ${ }^{1}$ ("Ständemehr" in German) have to agree to the proposed change.

If parliament intends to change or enact a new law, a referendum is not mandatory. All the same, Swiss citizens may demand a referendum on the proposed legislation by collecting at least 50000 signatures ("facultative referendum"). The proposed law change is rejected if $50 \%$ of the population votes against it in a referendum. A majority of cantons is not required.

Finally, citizens may also demand a constitutional amendment by referendum (called "initiative") by collecting at least 100000 signatures. Members of parliament are required to vote on the text of an initiative which serves as a parliamentary recommendation for the referendum. Parliament and the government cannot refuse an initiative unless it violates formal rules. However, they can work out a counter-proposal to the initiative which is presented to the voters at the same time as the initiative in a referendum.

Referendums results are available for every electoral district and for the whole period of analysis from the years 1996 to 2008 by the Swiss Federal Statistical Office and the Swissvotes Database. Decisions in parliament usually precede referendums by several months, the respective parliamentary decisions were made from 1995 to 2007 . We are able to compare legislative decisions by members of parliament with referendum outcomes on exactly the same legislative issues and with the same wording. Thus, we observe decisions of voters and members of parliament in the unique policy dimension which is defined by the referendum itself. This permits us to test empirically the effects of differences in the electoral system by analyzing whether members of parliament from smaller districts more effectively cater to the citizens' preferences by voting more with the majority while members of parliament from larger districts diverge more from the majority. Put differently, we can identify whether the electoral system has an influence on how well members of parliament represent their voters' interests.

As dependent variables we employ two indicator variables: The first indicator takes the value of one when a member of parliament does not vote as the majority of the whole Swiss population $(\mathrm{MP} \neq \mathrm{CH})$ and zero if he/she votes as the majority. The second indicator equals one when a member of parliament does not vote as the majority in his/her district $(M P \neq$ District). Consequently, the two dependent variables measure deviations by members of parliament from the will of the people at the national and the district level, respectively.

\subsection{Estimation equation}

Our econometric logistic model explaining deviations from the majority is given by:

$$
\begin{array}{r}
P(M P \neq C H)=\Lambda\left(\alpha_{0}+\alpha_{1} \text { Seats }+\sum_{j} \alpha_{j} \mathrm{x}_{\mathrm{j}}+\varepsilon\right) \\
P(M P \neq \text { District })=\Lambda\left(\alpha_{0}+\alpha_{1} \text { Seats }+\sum_{j} \alpha_{j} \mathrm{x}_{\mathrm{j}}+\varepsilon\right)
\end{array}
$$

The two dependent variables are binary measures. Therefore, we use a logistic (logit) model $(\Lambda=\exp (X) /(1+\exp (X))$ with $X$ as design matrix $)$. We estimate the impact of exogenous variables on the probability that a member of parliament votes against the majority of citizens in Switzerland $(M P \neq C H)$ in (1) or against his/her district's majority

\footnotetext{
${ }^{1}$ For historical reasons, there are 20 full cantons and 6 half cantons ("Halbkantone"). There is no important difference between full and half cantons except that the latter have only one member in the upper house, each, and that they only count with half weight when calculating the "Ständemehr".
} 
$(M P \neq$ District $)$ in (2). The equations are motivated theoretically by the expected positive impact of a higher number of seats a district has in parliament on the probability that a member of parliament deviates from the majority. Thus, we expect $\alpha_{1}>0$. For each coefficient we estimate robust standard errors. Standard errors are also clustered at the district level as the error terms for observations within a district can be correlated, and the assumption that the errors are independently and identically distributed might be violated. District clustering allows us to estimate cluster robust standard errors and provides a conservative test for our hypotheses.

Political decisions of members of parliament are not only influenced by the number of seats of their respective electoral district. In our case the sub-national units provide a broad empirical field within a common framework of identical basic characteristics as opposed to international comparisons. However, we include a number of political and economic control variables in the model. Their different impacts are represented by the coefficients $\alpha_{j}$. The empirical analysis includes data on referendum results, type of referendums, turnout, individual characteristics and party affiliations of members of parliament, as well as sociodemographic and economic variables characterizing the 26 Swiss cantons.

In addition to the variable Seats which measures effects of the electoral system, we control whether the district has voted as the majority of the national population by including a dummy variable which equals one if this is the case $($ Canton $=\mathrm{CH})$. Elected representatives to the national parliament may not only represent national interests as their mission would suggest. They may also try to please their local voters or engage in pork barrels (Milesi-Ferretti et al. 2002). Therefore we expect that a member of parliament is less likely (negative sign) to deviate from the national as well as the district's majority if his/her district votes in line with the majority of the national population.

Out of 102 referendums analyzed, 18 are constitutional changes initiated by the parliament. As mentioned above, constitutional proposals require mandatory referendums. With mandatory referendums, politicians know in advance that citizens have to confirm legislative decisions in a referendum; otherwise such proposal cannot be enacted. They know for sure that their decisions are compared with the district majority's will. Thus, we include a dummy variable which indicates whether a referendum was mandatory or not (RefMandatory). We expect a negative influence of mandatory referendums on the probability of a representative voting against the voters' majority at the national and the cantonal level. Moreover, we include a dummy variable to control for the influence of the 50 initiatives (RefInitiative) on divergence between citizens and members of parliament. Initiatives are often advanced by small political groups with specific interests. They are often clearly rejected by members of parliament and the majority of citizens. Thus, we expect a negative sign for divergence between politicians and voters in the case of initiatives. The 34 facultative referendums form the omitted category.

A district's voter turnout (Turnout) is always included in the estimations as a measure for perceived importance of the referendum. The sign of voter turnout is ambiguous, a priori. High voter turnout may reflect the fact that the issue of the referendum is considered as important. However, important issues for voters are also likely to be important issues for interest groups. Moreover, high voter turnout may be a sign of discontent with political decisions. Whether a high turnout correlates with a high probability that a representative votes in the same way as the majority of the voters depends on the relative importance he or she puts on voters versus interest groups and his personal linkages.

An individual representative may be more prone to departing from the majority's position when he/she can be more confident about re-election while new members of parliament 
may try to satisfy the majority. We control whether a representative is new to parliament or not (NewToParliament). We expect a negative effect of being new to parliament on divergence. Moreover, the vote margin with which each member of parliament has been elected may matters. Members of parliament with narrower margins might be more worried about reelection, thus making them more likely to correspond to voters' preferences. However, it may also be the case that exactly these representatives try to please lobbies to seek funds for reelection and are, thus, generally less likely to represent the majority of voters. To control for a possible bias of a narrow electoral margin we include a dummy variable which indicates whether a politician has been elected with the fewest number of votes on the list (NarrowMargin). We have no clear expectations for this variable.

"Duverger's Law" in political science (Duverger 1954) states that proportional representation leads to a multi-party system while a simple-majority favors a two-party system. As a consequence, members of parliament from plurality districts tend to be members of center parties while representatives from districts with proportional representation might be from all over the political spectrum. Thus, we also present estimations with controls for party affiliation. The electoral system induces different party positions. Once we control for these party positions, it is unclear whether there is still a direct effect of district magnitude on individual members of parliament or whether magnitude influences parties only. Therefore the inclusion of party affiliations serves as a very stringent and conservative test for the influence of the electoral system on individual members of parliament. Any effect captured by the Seats variable is a lower bound estimate for the influence of the electoral system on diverging from citizens' preferences. In our setting the center party called Christian Democrats (Christlich Demokratische Volkspartei CVP, in German) forms the omitted group. On a left-right scale for Switzerland, the large parties are commonly ordered as follows: Socialist Party SP (left); Christian Democrats CVP (center) and Liberals FDP (center); Swiss Peoples Party SVP (right). There are also a number of smaller parties with only very few representatives in parliament. Members of parliament from these parties often join the party group (the 'Fraktion') of the larger parties. We control for these smaller parties with separate dummies if they have more than one member of parliament over the whole sample period. ${ }^{2}$

Members of parliament also have to provide information on their interest affiliation with special interest groups, private companies and other institutions. We compiled data on the number of interest affiliations for each politician in parliament (Interests). According to Lizzeri and Persico (2001) politicians caring about the "spoils of office" may provide public goods differently under proportional versus winner-take-all systems. The empirical effect of the number of interest group affiliations on divergence between politicians and voters is ambiguous for several reasons: Firstly, especially politicians from the center are members of interest groups. Secondly, interests groups are very diverse: The Swiss Cancer Society is officially classed as an interest group as are mandates for financial institutions. Thus, if a large number of interest group affiliations mirrors a more central positioning of the respective politician, it may not induce divergence but rather align a politician with the majority.

Apart from controlling for the heterogeneity of politicians and parties, economic and social heterogeneity within an electoral district may play an important role. Besides electoral institutions, such as district magnitude, there are other factors which may influence the number of parties or other control variables (see, e.g., Ordeshook and Shvetsova 1994). ${ }^{3}$ Es-

\footnotetext{
${ }^{2}$ Formally, we exclude parties with less than 204 decisions in parliament and thus less than two members over the whole dataset (we analyze 102 referendums).

${ }^{3}$ For a number of different controls see, for example, Lijphart (1990), Neto and Cox (1997), Rae (1971) or Benoit (2001).
} 
pecially macroeconomic indicators such as the level of regional income as well as inequality have been used as controls (see Vatter 2003; Neto and Cox 1997). It is reasonable to assume that juggling heterogeneous interests could be challenging for a member of parliament if he/she tries to vote with the majority (see, e. g., Gerber and Lewis 2004). To control for the influence of intra-cantonal heterogeneity we use indicators of population density (Density), income inequality (Inequality) and regional income (Income). In line with existing empirical work on Switzerland, we always use a dummy for the Latin (i.e., French and Italian speaking) cantons. This dummy picks up cultural differences between those and the German speaking cantons.

Swiss voters have the possibility to change party list combinations at elections (panachages). Panachages refers to the possibility of voters to add candidates from other party lists to their chosen list. In cantons where a high number of ballot papers where changed (ChangedBallotPapers), political competition is likely to be high. Panachages may lead to more extreme and dispersed positions (see, e.g., Vatter 2003), as the possibility of altering the party list may increase the number of political positions of individual candidates. Thus, we expect a positive coefficient.

Moreover, we control for whether a referendum took place in the same year as the parliamentary election (RefElection). We expect that during such years, positions of individual politicians and the majority are less divergent.

As a final test of robustness, we analyze a number of additional variables measuring party discipline coded as voting against the party line (AgainstPartyLine) and the number of referendums on the same day (RefSameDay). We also introduce a continuous measure for the political distance between the district and the voters at the district level as well as national level by introducing the absolute difference in the "yes vote" of the district minus the "yes vote" at the national level (YesDiff).

Matching referendum data with individual voting records in parliament allows us to study 17674 decisions of members of parliament in all 102 referendums from 1996 to 2009. Note that members of parliament may be absent at votes due to sickness, voyage or other duties. All variables, their sources, and a number of descriptive statistics are given in Table 5 in Appendix.

Data for the independent control variables were obtained and matched from the Federal Statistical Office, the Swissvotes Database and the Swiss Parliamentary Services. ${ }^{4}$ Over the whole dataset, individual members of parliament diverge from the preferences of Swiss as well as district voter majority in approximately a third of the observed cases. The variable Seats ranges from one to 34 and over the whole dataset the cantonal majority's preferences equalnational majority in approximately $90 \%$ of the cases.

The two dependent variables are correlated, i.e., when a member of parliament votes with the district majority he/she is likely to vote as the Swiss majority too. Figure 1 provides two histograms for the respective dependent variables.

A great number of individual members of parliament rarely diverge from the majority's preferences. However, very few politicians tend to diverge in more than $50 \%$ of the cases from the preferences of the majority of the citizens.

\footnotetext{
${ }^{4}$ See http://www.bfs.admin.ch/ (Federal Statistical Office), http://www.swissvotes.ch/ (Swissvotes), and http://www.parlament.ch (Swiss Parliamentary Services) for the respective databases and contact information. Daniel Schwarz from the IPW in Berne (http://www.ipw.unibe.ch) provided part of the parliamentary votes data which are matched with the other datasets.
} 
Diwergence from Swiss voters

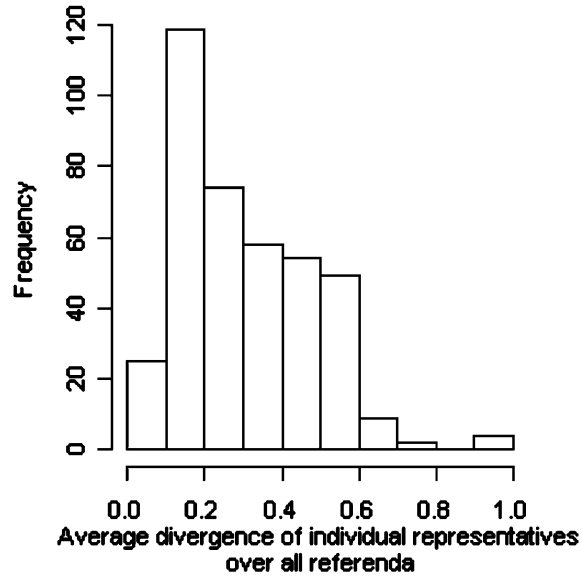

Dwergence from district voters

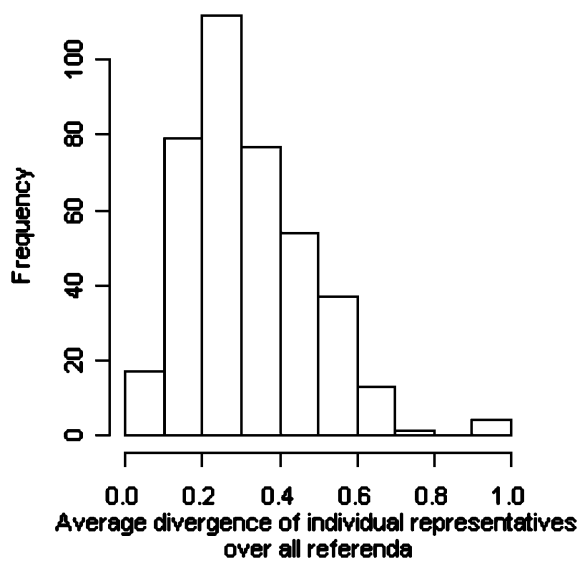

Notes: Histograms are based on the average number of times an individual member of parliament votes against the majority of Swiss voters (left panel) and the majority of district voters (right panel) over the years 1996 to 2008.

Fig. 1 Divergence between members of parliament and majority preferences

\section{Empirical results}

\subsection{Baseline results}

Table 2 presents our main empirical results for the variables measuring whether a member of parliament diverges from the majority of the Swiss population $(M P \neq C H)$ in specifications (1) to (3) and whether he/she diverges from the district's majority $(M P \neq D$ istrict $)$ in specifications (4) to (6). All specifications report robust standard errors with clustering at the cantonal (district) level. Next to each coefficient we report the change in the probability to diverge from the respective majority. The discrete effects for the variables represent a change from the first quartile to the third quartile for continuous variables and a change from zero to one for dummy variables while all other variables are held fixed at their medians. As we are also interested in the significance of the discrete effects we calculate robust standard errors for the changes in the probability using the Delta method. The delta method is a numerical method to achieve the approximate probability distribution of an estimator based on a generalized central limit theorem. Especially for interaction effects of logistic models Ai and Norton (2003) suggest the delta method to calculate standard errors of discrete effects for correct estimation.

Turning to specifications (1) and (4) first, we find that members of parliament from districts with a higher number of seats tend to diverge significantly more from the national majority's decisions (1) and the majority in their district (4) as suggested by the theoretical discussion, i.e., the seats variable has a positive sign and is significant at the $1 \%$ level in both specifications. If the district's majority votes as the majority of the population, members of parliament are less likely to disagree with citizens as the negative and significant coefficient of $($ Canton $=\mathrm{CH})$ indicates. In mandatory referendums (RefMandatory) members of parliament diverge less from citizens' preferences in Switzerland as a whole as well as from citizens' preferences in their respective district. The same holds true for initiatives 


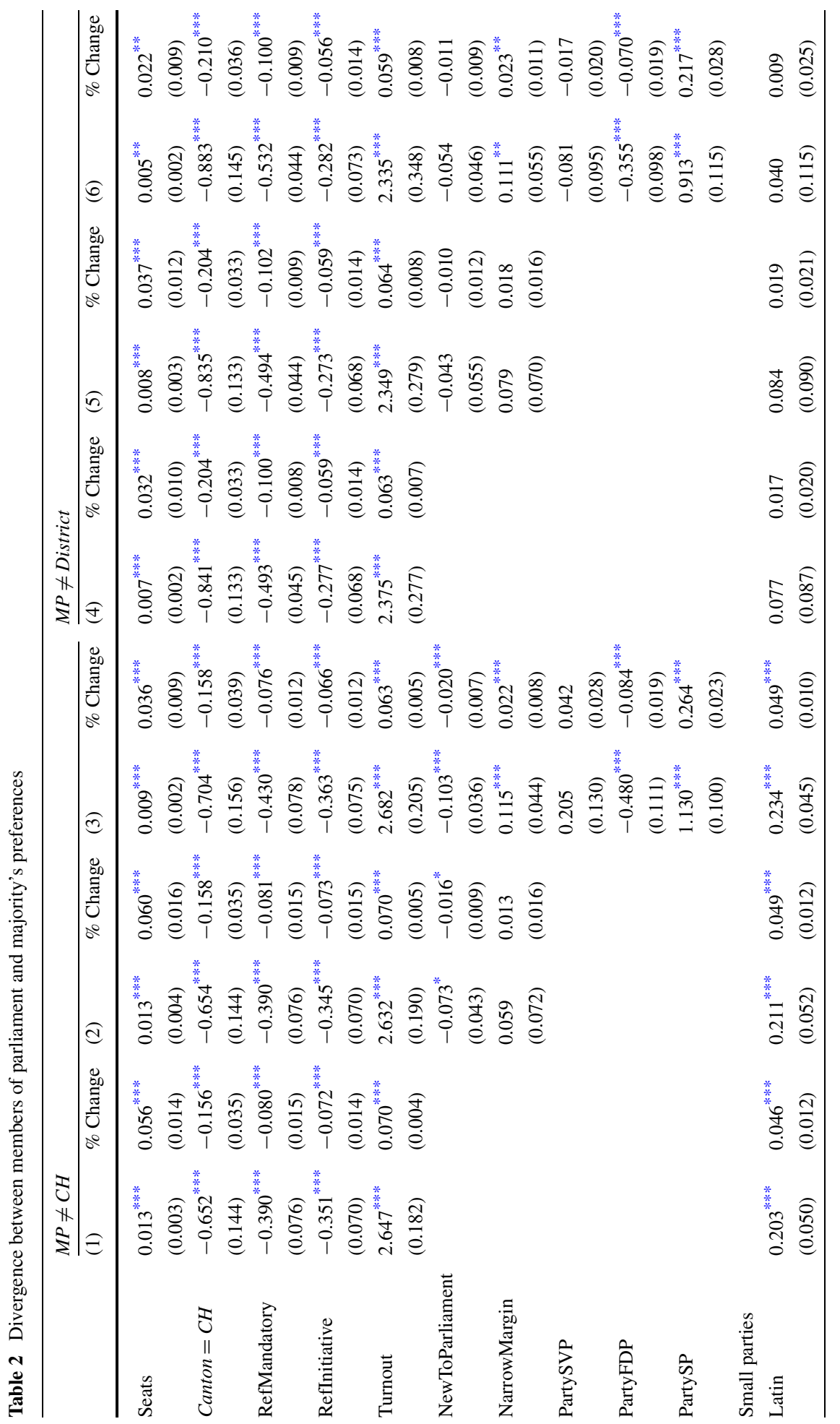




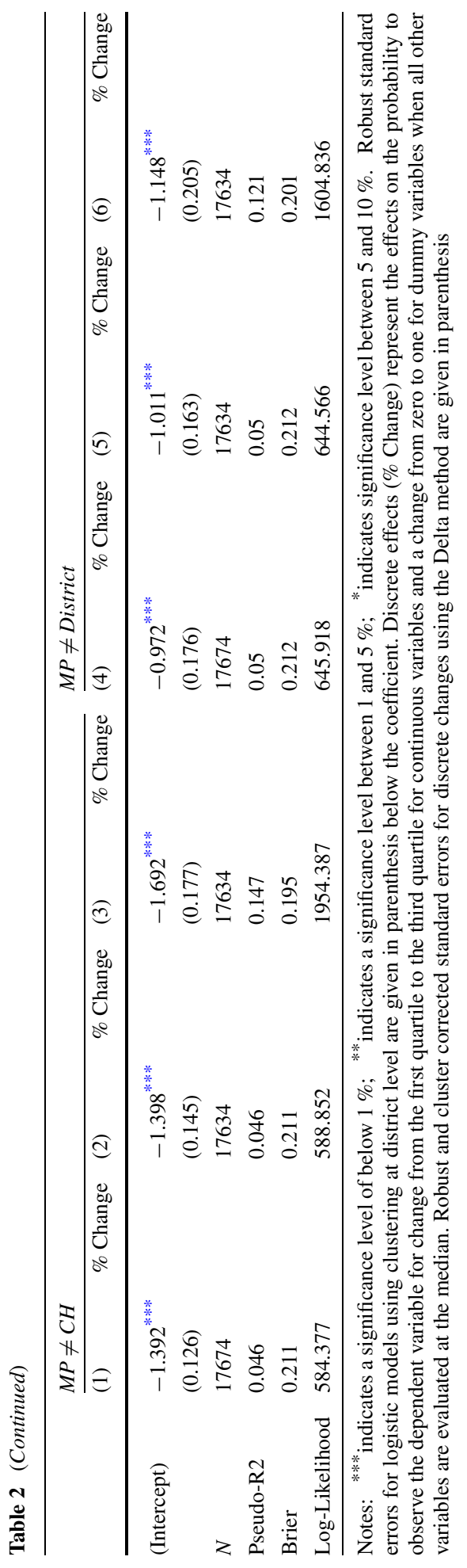


(RefInitiative) compared to the base category of facultative referendums. This could have been expected as initiatives are often rejected by members of parliament and voters which leads to less divergence. However, the negative effect of mandatory referendums is larger in absolute terms than the negative effect of initiatives. Higher district voter turnout translates into an increased likelihood of the representative deviating from the national and cantonal majorities. Members of parliament from Latin cantons tend to vote less often with the majority for both measures but the effect is insignificant for diverging from the cantonal voter's position $(M P \neq$ District $)$.

As shown next to each coefficient in column (1), a discrete increase in the number of seats from the first to the third quartile increases the probability of a representative voting against the majority of the population $(M P \neq C H)$ by 5.6 percentage points when all remaining variables are at their median values. A change from pure plurality with one seat to a proportional system (median number of seats) would increase the probability of voting against citizens' preferences by 2.9 percentage points. As expected, these effects of the electoral system are marginally smaller when the dependent variable is voting against the district population $(M P \neq D$ istrict $)$. Increasing the number of seats from the first to the third quartile raises the probability of voting against the district's majority by 3.2 percentage points. Moving from pure plurality (one seat) to proportional representation (median number of seats) would increase the probability of voting against the district's preferences by 1.7 percentage points. Discrete changes of Seats for both dependent variables are significant at the $1 \%$ level. Members of parliament from multi-member districts diverge from the position of the national and the cantonal median voter but moving from plurality to a more proportional system has a lower influence on diverging from the electoral district (3.2 percentage points) than from the majority of the Swiss population (5.6 percentage points). In other words, members of parliament from a large district identify less with their district voter's majority of their district than members of parliament from a small district (column 4), but the divergence is even stronger at the national level (column 1). This is consistent with the view that members of parliament elected at a district level tend to favor their own electorate. The effect of Seats in specifications (1) and (4) are in their sizes comparable to the influence of other control variables such as initiatives, turnout and language. Only the dummy $($ Canton $=\mathrm{CH}$ ) has a significantly higher influence on the probability to diverge in both specifications as expected.

In specifications (2) and (5) we check whether electoral pressure has an effect on diverging from the majority and whether the influence of Seats remains stable. We include two additional controls, one for whether a politician was elected to parliament for the first time, and one for whether the electoral margin by analyzing whether he or she is the last on the party list being elected. The variable NewToParliament is negative and significant as expected which suggests that politicians who were elected already several times tend to be more prone to depart from the majority. The variable NarrowMargin is insignificant. But most importantly, the inclusion of all these controls does not influence the effect of the variable Seats which remains significant and even slightly increases in size.

In cantons with only a small number of seats in parliament the competition for these seats will usually be among center parties as they are more likely to represent the decisive voter. In large districts with many seats more parties enter the competition. If the number of seats is sufficiently large, parties which focus on votes at the boundary of the political spectrum may also win seats. In this case party affiliation of members of parliament itself could explain the observed positive impact of seats on the probability of diverging from the majority. The number of seats would then only have an indirect effect through a greater number of parties on diverging from the majority of voters instead of a direct effect. In 
specifications (3) and (6) we include political party affiliations of members of parliament as a very conservative test and lower bound for the influence of the electoral system on diverging from the national majority (3) and the district majority (6). We present the party dummy coefficients for parties in government but also include dummies for smaller parties. Members of parliament from parties which are commonly denoted as left (SP) and right (SVP) are more likely to vote against the majority's interest then center parties (FDP is a center party as is CVP which forms the omitted category). Nevertheless, the effect of Seats remains positive and significant. The discrete effects indicate that moving from plurality to more proportional representation increases the probability of a member of parliament to diverge from the majority's preferences in the population by 3.6 percentage points (column 3 ) and increases the probability to diverge from the district's majority by 2.2 percentage points (column 6).

Summarizing these results, we find strong support for the hypothesis that increasing the number of representatives per district increases, ceteris paribus, an individual member of parliament's incentives to diverge from voters' preferences. Moving from plurality to more proportional representation increases divergence from the national population between 3.6 and 6.1 percentage points and it increases divergence from the district population between 2.2 and 3.8 percentage points.

\subsection{Robustness}

All robustness tests are reported in Table 3.

District heterogeneity may have an influence on the extent to which members of parliament diverge from citizens' decisions as argued by Gerber and Lewis (2004). Therefore, we include in logistic regressions (1) and (2) a number of variables measuring district heterogeneity. Overall, including heterogeneity does not have an influence on the size or significance of the variable Seats. The probability of diverging from the national (1) and the district majority (2) increases when moving from plurality to proportional representation as the number of seats has a positive and significant influence in both specifications. In terms of their sizes the coefficients are comparable to earlier estimates.

Members of parliament may face stronger political competition if voters often change party list combinations in elections. Swiss voters have the possibility to change the party list by so called "panachages", i.e., they can put a person from a certain party on the list of another. We measure possible effects of higher electoral competition through "panachages" by including the fraction of ballot papers which were changed in national elections (ChangedBallotPapers). Moreover, we take account of election years as an additional measure for political competition and the number of interest group affiliations.

When turning to specifications (3) and (4), the extent of panachage (ChangedBallotPapers) has the expected positive effect on divergence. The effect of (RefElection) is consistently negative but does not reach statistical significance. The number of interest group affiliations is also negative and statistically significant. Thus, as argued before, a larger number of interest affiliations does not necessarily induce divergence but instead aligns a politician with the majority if more interest group affiliations represent a broader positioning of the politician. Controlling for these measures of political competition has no effects on the sign or the significance of the Seats variable. This is shown in specifications (3) and (4) for members of parliament diverging from the national majority and the district's majority, respectively. Politicians from districts with more seats in parliament vote more often against the majority of the population and the population of their electoral district, i.e., their canton. 


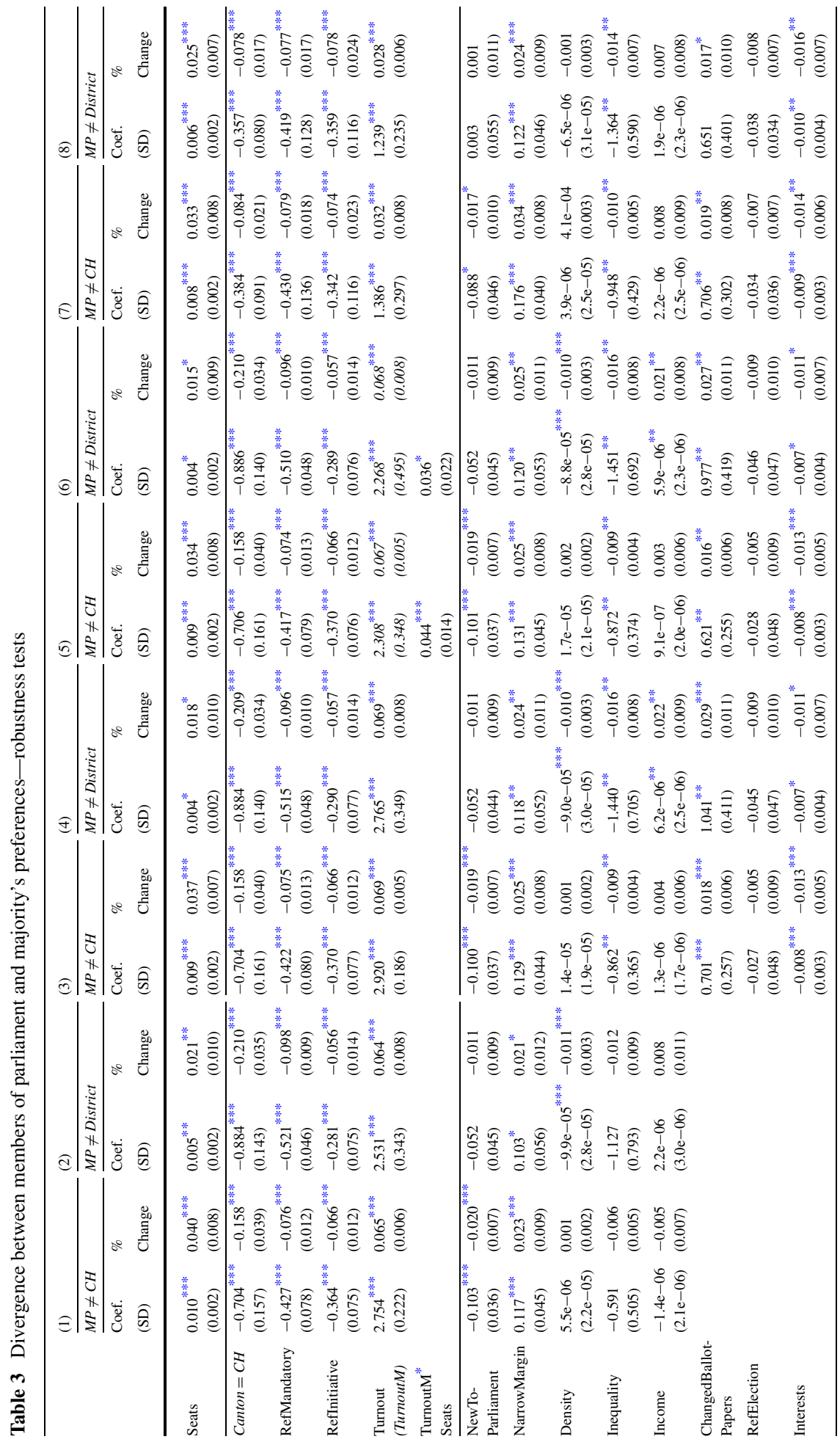




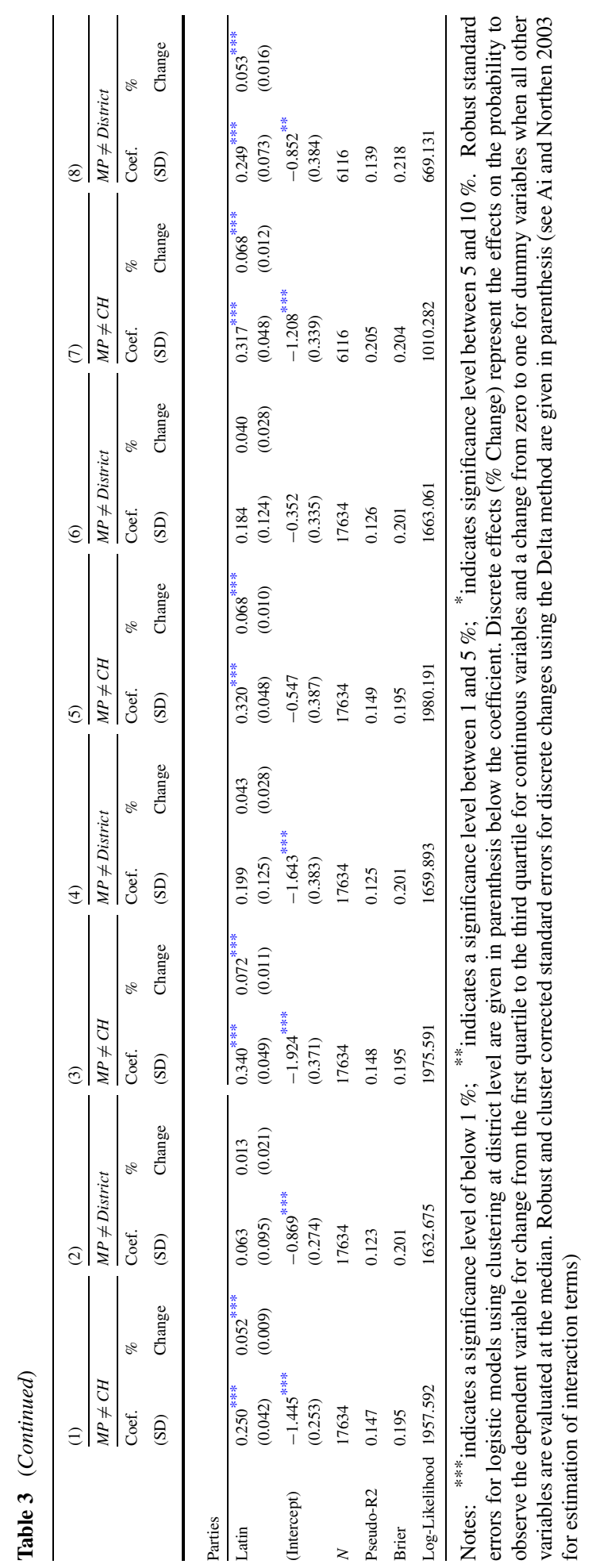


The above results indicate a higher probability that politicians deviate from both national and cantonal voter majority if turnout is high. If turnout is high under proportional representation it is likely that politicians are even more tempted to care for their specific (cantonal) voter groups instead of voting along with the national majority in particular. To test this differential hypothesis we interact the variables Turnout and Seats. The interaction serves to identify if members of parliament from larger districts with more seats diverge more from the population of voters when the referendum has a high participation rate. Applied researchers often estimate interaction terms to infer how the effect of one independent variable on the dependent variable depends on the magnitude of another independent variable. Unfortunately, the intuition from linear regression models does not extend to nonlinear models. For our results we apply the reasoning of Ai and Norton (2003) that the discrete effects represent the total effect of a change in the probability, i.e., sum of base and interaction effect. ${ }^{5}$ Politicians from larger cantons are even more likely to vote against the national majority than politicians from small cantons if turnout is high. This can be seen from column (5), where we include (TurnoutM), the deviation from the median turnout, and the interaction term (Seats x TurnoutM). Participation rates which are higher than the median participation rate also raise the probability that members of parliament vote against the majority of their district's constituents but as expected the interaction term in (6) is less significant. When turnout is high, the incentives of the representatives to diverge from the national majority in order to align with the district majority are larger as members of parliament are elected within districts.

Finally, we restrict our dataset to referendums where the parliamentary majority was less clear, i.e., we focus on referendums where less than $65 \%$ of members of parliament agreed to, or rejected, the proposals. The results are presented in columns (7) and (8). Again, the effect of the electoral system is clear. Even for issues that passed parliament with a relatively small margin, we find that as the number of seats increases, the probability to diverge from the national majority's preferences raises and the probability to diverge from the majority's preferences of the district increases too.

\subsection{Bayesian model averaging results}

The basic methodology to analyze different variables on decision outcome measures consists of running cross-section regressions including the main variable of interest and a number of other controls (see Vatter 2003; Ordeshook and Shvetsova 1994). The problem with this approach is that economists who work empirically might not exactly know which independent control variables should be included in their regressions. Clearly, the choice should be guided by theory. It is also clear though, that variable selection can have an important effect on the results and missing out explanatory variables might introduce considerable bias. In final robustness tests, we deal with the problem of variable selection by performing Bayesian Model Averaging (see Raftery 1995; Raftery et al. 1997).

The main idea behind Bayesian Model Averaging (BMA) is to estimate the distribution of unknown parameters of interest across a large number of different models (model space). In contrast to classical estimations, model averaging copes with model uncertainty by allowing all possible models to be considered a priori, which consequently reduces the bias of the parameters of interest. The Bayesian approach is feasible and has been applied to various problems in economics by other authors such as Fernandez et al. (2001) or Sala-i-Martin et

${ }^{5}$ We use the Delta method again to estimate the standard errors of the total effects. 
al. (2004). Hoeting et al. (1999) give various other examples and mention possible applications. BMA asks the researcher to specify possible regressors that might have an impact on the respective measure whether a member of parliament votes with the majority of the population or the majority of the district. The interpretation of the estimates from BMA is straightforward as we can calculate conditional means and standard deviations which can be interpreted similarly to standard coefficients form logistic regression models. Furthermore, a posterior inclusion probability for any variable can be calculated which gives the probability that any specific variable is included in a model, i.e., the posterior inclusion probability gives an indication of the importance of the variable over the whole model space analyzed. ${ }^{6}$

Results of Bayesian Model Averaging are presented in Table 4.

We include all independent control variables from our dataset as well as a constant, but exclude party dummies as BMA does not allow us technically to treat them as fixed effects. The comparatively large number of controls may lead to problems of multi-collinearity, numerical instability, and computational imprecision. To evaluate the upper limit of possible numerical errors we calculate a "condition number" as proposed in numerical mathematics (see Schwarz and Köckler 2004). The condition number is defined as the ratio of the largest to the smallest non-zero singular value of the full design matrix including all variables. Generally speaking, a very high condition number will lead to problems with numerical estimations independent of the statistical software used. Computers work with a certain numerical precisions. The higher the condition number, the higher the loss of a computer's numerical precision. The condition number for our full design matrix with all controls is approximately $1.5 \times 10^{6}$ indicating that the numerical problem is well-conditioned for digital computation. Therefore, we are neither likely to have problems with precision nor with correlation between explanatory variables, as the BMA algorithm itself chooses the variables having the highest effect according to the Bayesian Information Criterion.

Columns (1) to (3) present the results of BMA for the dependent variable indicating that a member of parliament votes against the population. We include all variables of our dataset for the BMA procedure, i.e., voting against the party line (AgainstPartyLine), the number of referendums at the same day (RefSameDay) and the absolute difference in the "yes vote" of the district minus the "yes vote" at the national level (YesDiff).

The conditional mean of the variable Seats is positive and highly significant as shown in column (1). This indicates that the average effect of the size of a district on diverging from the national majority's preferences regarding all estimates over the whole model space is positive. The other control variables have mostly the same signs concerning the conditional mean in BMA as they have in the other estimates presented above. Concerning the additional control variables, all three additional controls turn out to be significant when looking at the whole model space. In column (2) we perform a Wilcoxon signed-rank test for the sign of the posterior mean conditional on inclusion. In the averaging procedure of BMA different models are estimated. In each of these models the sign of the variable under consideration is taken. It might be the case, for example, that the electoral system measured by seats has a negative impact on diverging from national majority's interests in some specific models but a positive impact in others and on average. We test for this possibility and present the resulting p-values in column (2), i.e., we test whether the coefficients of the diverse models have the same sign as the reported posterior conditional mean. At the $1 \%$ level we can reject that the variable seats enters other models of the whole model space with a negative sign. We

${ }^{6}$ Further explanations on BMA and applications can be found in the literature (Raftery et al. 1997 and the follow up literature). We stipulate $1 / 2$ as the prior probability of including any variable in the model. 
Table 4 Divergence between members of parliament and majority's preferences-BMA

\begin{tabular}{|c|c|c|c|c|c|c|}
\hline \multirow{3}{*}{ Seats } & \multicolumn{3}{|l|}{$M P \neq C H$} & \multicolumn{3}{|l|}{$M P \neq$ District } \\
\hline & $\begin{array}{l}\text { Cond. Mean } \\
\text { (Cond. SD) }\end{array}$ & Sign Test & Inc. Proba. & $\begin{array}{l}\text { Cond. Mean } \\
\text { (Cond. SD) }\end{array}$ & Sign Test & Inc. Proba. \\
\hline & $\begin{array}{l}0.013 \\
(0.002)\end{array}$ & 0.000 & 99.9 & $\begin{array}{l}0.005 \\
(0.002)\end{array}$ & 0.006 & 69.4 \\
\hline CantonCHMatch50 & $\begin{array}{l}-0.615 \\
(0.062)\end{array}$ & 0.000 & 99.9 & $\begin{array}{l}-0.849 \\
(0.055)\end{array}$ & 0.000 & 99.9 \\
\hline RefObligatory & $\begin{array}{l}-0.302 \\
(0.052)\end{array}$ & 0.000 & 99.9 & $\begin{array}{l}-0.469 \\
(0.052)\end{array}$ & 0.000 & 99.9 \\
\hline RefInitiative & $\begin{array}{l}-0.328 \\
(0.037)\end{array}$ & 0.000 & 99.9 & $\begin{array}{l}-0.254 \\
(0.036)\end{array}$ & 0.000 & 99.9 \\
\hline Turnout & $\begin{array}{l}2.818 \\
(0.216)\end{array}$ & 0.000 & 99.9 & $\begin{array}{l}2.572 \\
(0.205)\end{array}$ & 0.001 & 99.9 \\
\hline NewTo-Parliament & $\begin{array}{l}-0.045 \\
(0.034)\end{array}$ & 1.000 & 1.0 & EXC & & \\
\hline NarrowMargin & $\begin{array}{l}0.069 \\
(0.036)\end{array}$ & 0.371 & 4.1 & $\begin{array}{l}0.076 \\
(0.036)\end{array}$ & 0.181 & 4.4 \\
\hline PopulationDensity & $\mathrm{EXC}$ & & & EXC & & \\
\hline IncomeInequality & $\begin{array}{l}-2.467 \\
(0.487)\end{array}$ & 0.000 & 99.9 & $\begin{array}{l}-1.755 \\
(0.432)\end{array}$ & 0.003 & 98.5 \\
\hline GDPperCapita & $\mathrm{EXC}$ & & & EXC & & \\
\hline ChangedBallot-Papers & $\begin{array}{l}0.245 \\
(0.211)\end{array}$ & 1.000 & 0.8 & EXC & & \\
\hline RefElection & $\mathrm{EXC}$ & & & $\begin{array}{l}-0.069 \\
(0.040)\end{array}$ & 0.371 & 2.3 \\
\hline Interests & $\begin{array}{l}-0.029 \\
(0.003)\end{array}$ & 0.000 & 99.9 & $\begin{array}{l}-0.023 \\
(0.003)\end{array}$ & 0.000 & 99.9 \\
\hline AgainstPartyLine & $\begin{array}{l}1.192 \\
(0.059)\end{array}$ & 0.000 & 99.9 & $\begin{array}{l}0.886 \\
(0.058)\end{array}$ & 0.001 & 99.9 \\
\hline RefSameDay & $\begin{array}{l}0.020 \\
(0.009)\end{array}$ & 0.371 & 9.6 & EXC & & \\
\hline TimeToRef & $\begin{array}{l}0.001 \\
(0.000)\end{array}$ & 0.000 & 99.9 & EXC & & \\
\hline YesDiff & $\begin{array}{l}1.142 \\
(0.389)\end{array}$ & 0.181 & 35.1 & $\begin{array}{l}0.595 \\
(0.370)\end{array}$ & 1.000 & 1.3 \\
\hline Latin & $\begin{array}{l}0.236 \\
(0.049)\end{array}$ & 0.000 & 99.9 & $\begin{array}{l}0.106 \\
(0.043)\end{array}$ & 0.181 & 9.1 \\
\hline (Intercept) & $\begin{array}{l}-0.800 \\
(0.212)\end{array}$ & 0.000 & 99.9 & $\begin{array}{l}-0.224 \\
(0.206)\end{array}$ & 0.000 & 99.9 \\
\hline
\end{tabular}

Notes: For the Bayesian Model Averaging (BMA) results, the conditional mean (Cond. Mean) and standard deviation (Cond. SD) are conditional on inclusion of the variable in the model. BMA results were obtained using the software of the R Project for Statistical Computing with the BMA package (see Raftery et al. 2009). EXC indicates variables which were excluded from the evaluation by the "Leaps and Bounds algorithm" perceding BMA (see Hoeting et al. 1999). The sign-test in columns (2) and (5) is a Wilcoxon signed-rank test for the sign of the variable over all models. The p-value of the sign tests indicates whether the coefficient is on the same side zero as its posterior mean conditional on inclusion. Columns (3) and (6) give the posterior inclusion probability of all variables 
also calculate the posterior inclusion probability of all variables in column (3). The inclusion probability of seats is at the maximum value, i.e. the variable should always be included.

Finally, columns (4) to (6) present BMA results when the dependent variable indicates whether a member of parliament votes against the majority of voter of his/her district. The posterior mean conditional on inclusion for seats is negative and highly significant. Moreover, the Wilcoxon signed-rank test for the sign of the posterior mean conditional on inclusion indicates that the positive sign is not just a statistical artifact of aggregation. We can reject the hypothesis that the conditional mean is negative at the $1 \%$ level. The posterior inclusion probability is in the range of other important control variables.

\section{Summary and conclusions}

\subsection{Summary}

If a district is large and has many seats in national parliament, its electoral system exhibits proportional representation. In small districts with fewer seats, elections within the district follow a plurality rule. "Winner takes all" plurality districts with only one seat represent the extreme case. Good systems of political representation align citizen's preferences with legislator's behavior (see Gerber and Lewis 2004). We extend the existing literature by analyzing whether the district magnitude induces members of parliament to diverge significantly more often from the majority's preferences when moving from small districts with few seats to proportional representation in large districts.

To measure whether members of parliament deviate from the majority's preferences, we take advantage of unique data from a quasi-natural experiment in Switzerland: Swiss referendums reflect voting behavior of citizens and thus how the majority values certain policy proposals against the status quo. Referendum results can be matched with voting data for members of parliament on exactly the same political issues with exactly the same wording. In Switzerland, the electoral system changes from pure plurality to proportional representation as district size increases. Hence, the referendums institution allows us to identify empirically whether members of parliament from large districts with proportional representation diverge significantly more from the majority's preferences than members of parliament from districts with plurality or close to plurality rules. The more often members of parliament vote in the same way as the majority of the electorate, the better they represent the majority's interests.

Our empirical results with a logistic regression model and district clustering strongly indicate that members of parliament from small districts with fewer seats are more likely to vote in the same way as their local constituents as well as the majority of the national population. In other words, decisions of members of parliament and the majority diverge more in larger districts with many seats than in small districts. We also find evidence for a direct influence of the number of seats on the deputies' behavior. In contrast to part of the literature, the electoral system not only affects members of parliament via the positions of their parities. Individual members of parliament from large districts deviate more often from the majority's preferences than members from small districts even if we control for party membership and a number of other important factors.

\subsection{Policy conclusions}

Small district magnitude tends to better align individual deputies' decisions with the majority's preferences while proportional representation in large districts leads to more divergence. Under plurality rule, as measured by a low number of seats per district, decisions 
of individual members of parliament correspond most closely to district voters' preferences as well as national voters' preferences. Although positions of national and district majority voters are highly correlated, our results indicate that members of parliament align their decisions more to their district's majority.

Our research highlights the importance of analyzing incentives in the electoral system which may induce politicians to converge or diverge from the majority's preferences. To insure that individual politicians closely act according to the majority's will, an electoral reform towards smaller electoral district sizes could be envisioned. However, such reforms would have to be followed with caution. Firstly, it might be argued that systems where politicians closely follow the majority lead to under-representation of the minority's interests. Secondly, our analysis focuses on individual choices by politicians and how individual politicians represent the majority's preferences. In parliament, more politicians from larger districts can compensate their individual errors and divergence. Thus, a higher number of politicians may lead to worse individual incentives but the aggregate decisions, i.e., the decision of the majority of representatives, can well be closer to voter's preferences than when a single politician would decide (see Stadelmann et al. 2010).

These two reflections would need to be investigated more thoroughly before conclusive policy advice may be offered. We hope that our approach stimulates further research and brings a new perspective into discussions on institutional reforms. The approach presented in this article moves beyond political outcomes such as the seat distribution between parties and policy outcomes such as fiscal measures and targets directly on voter preferences in a very broad sense.

Finally, our empirical results also highlight the importance of institutions. Politicians substantially diverge from the majority's preferences. Referendums help citizens to correct parliamentary decisions which go against their interests and may serve as a control mechanism for politicians.

Acknowledgements We are grateful to Bruno S. Frey, Michael Funk, Volker Grossmann, Marius Osterfeld, Fabio Padovano, Friedrich Schneider, Daniel Schwarz, Eva Spring, Jan-Egbert Sturm and the participants of the seminar for Political Economy and Organization at the University of Zurich, the Young Researcher Seminar at the University of Fribourg, the Annual Meeting of the European Public Choice Society 2010 in Izmir and the Spring Meeting of Young Economists 2010 in Luxembourg for illuminating and inspiring discussions.

\section{Appendix}

Table 5 Data description \& sources

\begin{tabular}{|c|c|c|c|c|c|c|}
\hline Variable & Description \& Source & 1st Qu. & Median & Mean & 3rd Qu. & SD \\
\hline$M P \neq C H$ & $\begin{array}{l}\text { Indicator variable: Member of } \\
\text { parliament against majority of Swiss } \\
\text { voters. Swiss Parliamentary Services } \\
\text { and Final Votes Dataset }\end{array}$ & 0.000 & 0.000 & 0.320 & 1.000 & 0.467 \\
\hline$M P \neq$ District & $\begin{array}{l}\text { Indicator variable: Member of } \\
\text { parliament against majority of voters } \\
\text { in canton (district). Swiss } \\
\text { Parliamentary Services and Final } \\
\text { Votes Dataset }\end{array}$ & 0.000 & 0.000 & 0.325 & 1.000 & 0.468 \\
\hline
\end{tabular}


Table 5 (Continued)

\begin{tabular}{|c|c|c|c|c|c|c|}
\hline Variable & Description \& Source & 1st Qu. & Median & Mean & 3rd Qu. & $\mathrm{SD}$ \\
\hline Seats & $\begin{array}{l}\text { Canton's number of seats in the } \\
\text { national council. Federal Statistical } \\
\text { Office }\end{array}$ & 7.000 & 12.000 & 15.820 & 27.000 & 10.854 \\
\hline Canton $=\mathrm{CH}$ & $\begin{array}{l}\text { Indicator variable: If majority of voters } \\
\text { in a member of parliment's canton } \\
\text { votes as majority of voters in } \\
\text { Switzerland. Swiss Parliamentary } \\
\text { Services and Final Votes Dataset }\end{array}$ & 1.000 & 1.000 & 0.904 & 1.000 & 0.294 \\
\hline RefMandatory & $\begin{array}{l}\text { Indicator variable: If referendum is an } \\
\text { obligatory referendum value is } 1 \\
\text { (necessary for an amendment to the } \\
\text { constitution initiated by the } \\
\text { parliament). Swissvotes Database }\end{array}$ & 0.000 & 0.000 & 0.178 & 0.000 & 0.383 \\
\hline RefInitiative & $\begin{array}{l}\text { Indicator variable: If referendum is an } \\
\text { initiative value is } 1 . \text { Swissvotes } \\
\text { Database }\end{array}$ & 0.000 & 0.000 & 0.435 & 1.000 & 0.496 \\
\hline Turnout & $\begin{array}{l}\text { Share of entitled voters in member of } \\
\text { parliament's home canton casting a } \\
\text { vote in referendum. Swissvotes } \\
\text { Database }\end{array}$ & 0.384 & 0.443 & 0.442 & 0.503 & 0.086 \\
\hline NewToParliament & $\begin{array}{l}\text { Indicator variable: If MP is a member } \\
\text { of parliament for less than a legislature } \\
\text { value is } 1 . \text { Swiss Parliamentary } \\
\text { Services }\end{array}$ & 0.000 & 0.000 & 0.419 & 1.000 & 0.493 \\
\hline NarrowMargin & $\begin{array}{l}\text { Indicator variable: If MP is elected } \\
\text { with the fewest number of votes on } \\
\text { his/her list or is single candidate on } \\
\text { list, value is } 1 . \text { Federal Statistical } \\
\text { Office. }\end{array}$ & 0.000 & 1.000 & 0.533 & 1.000 & 0.499 \\
\hline Density & $\begin{array}{l}\text { Inhabitants per } \mathrm{km}^{2} . \text { Federal } \\
\text { Statistical Office }\end{array}$ & 159.4 & 229.3 & 509.4 & 523.6 & 868.0 \\
\hline Inequality & $\begin{array}{l}\text { Gini coefficient of income inequality } \\
\text { in } 2003 \text {. Federal Statistical Office }\end{array}$ & 0.357 & 0.386 & 0.389 & 0.409 & 0.041 \\
\hline Income & $\begin{array}{l}\text { GDP per Capita in } 2005 \text { Swiss Francs. } \\
\text { Federal Statistical Office }\end{array}$ & 43950.0 & 48990.0 & 52380.0 & 60820.0 & 12520.2 \\
\hline ChangedBallotPapers & $\begin{array}{l}\text { Share of ballot papers which have been } \\
\text { altered (e.g. cross voting) by the voters } \\
\text { in the last election of the canton's } \\
\text { National Councilors. Federal } \\
\text { Statistical Office }\end{array}$ & 0.513 & 0.578 & 0.557 & 0.644 & 0.102 \\
\hline RefElection & $\begin{array}{l}\text { Indicator variable: If the referendum } \\
\text { took place in the same year as } \\
\text { elections took place value is } 1 . \\
\text { Swissvotes Database }\end{array}$ & 0.000 & 0.000 & 0.221 & 0.000 & 0.415 \\
\hline Interests & $\begin{array}{l}\text { Number of interest groups affiliations. } \\
\text { Swiss Parliamentary Services }\end{array}$ & 3.000 & 6.000 & 8.249 & 11.000 & 7.139 \\
\hline AgainstPartyLine & $\begin{array}{l}\text { Indicator variable: If MP does not } \\
\text { follow party line value is } 1 \text {. If MP } \\
\text { follows party line or free vote value is } \\
0 . \text { Swissvotes Database }\end{array}$ & 0.000 & 0.000 & 0.077 & 0.000 & 0.266 \\
\hline
\end{tabular}


Table 5 (Continued)

\begin{tabular}{|c|c|c|c|c|c|c|}
\hline Variable & Description \& Source & 1st Qu. & Median & Mean & 3rd Qu. & SD \\
\hline RefSameDay & $\begin{array}{l}\text { Number of referenda taking place at } \\
\text { the same day as the referendum under } \\
\text { consideration. Swissvotes Database }\end{array}$ & 2.000 & 3.000 & 3.726 & 5.000 & 1.993 \\
\hline TimeToRef & $\begin{array}{l}\text { Number of days between final vote in } \\
\text { parliament and referendum. } \\
\text { Swissvotes Database }\end{array}$ & 171.000 & 247.000 & 273.900 & 352.000 & 131.117 \\
\hline YesDiff & $\begin{array}{l}\text { Absolute difference in the "yes vote" } \\
\text { share of the district minus the "yes } \\
\text { vote" share at the national level. } \\
\text { Swissvotes Database }\end{array}$ & 0.019 & 0.042 & 0.055 & 0.077 & 0.050 \\
\hline PartySVP & $\begin{array}{l}\text { Indicator variable: If member of } \\
\text { parliament belongs to the SVP (Swiss } \\
\text { People's Party) value is } 1 \text {. Swiss } \\
\text { Parliamentary Services }\end{array}$ & 0.000 & 0.000 & 0.212 & 0.000 & 0.409 \\
\hline PartyFDP & $\begin{array}{l}\text { Indicator variable: If member of } \\
\text { parliament belongs to the FDP } \\
\text { (Liberals) value is } 1 . \text { Swiss } \\
\text { Parliamentary Services }\end{array}$ & 0.000 & 0.000 & 0.210 & 0.000 & 0.407 \\
\hline PartySP & $\begin{array}{l}\text { Indicator variable: If member of } \\
\text { parliament belongs to the SP } \\
\text { (Socialists) value is } 1 . \text { Swiss } \\
\text { Parliamentary Services }\end{array}$ & 0.000 & 0.000 & 0.261 & 1.000 & 0.439 \\
\hline Small parties & $\begin{array}{l}\text { Separate indicator variables for } \\
\text { smaller parties: GPS (Greens), EVP } \\
\text { (Evangelic People's Party), LPS } \\
\text { (Liberal Party), FPS (Freedom Party). } \\
\text { Swiss Parliamentary Services }\end{array}$ & & & & & \\
\hline Latin & $\begin{array}{l}\text { Indicator variable: If the canton is } \\
\text { largely French or Italian speaking } \\
\text { value is } 1 . \text { Federal Statistical Office }\end{array}$ & 0.000 & 0.000 & 0.272 & 1.000 & 0.445 \\
\hline
\end{tabular}

Notes: Descriptive statistics are based on 17674 decisions of members of parliament on 102 referenda from 1996 to 2008. Data sources indicated next to variable descriptions

\section{References}

Ai, C., \& Norton, E. C. (2003). Interaction terms in logit and probit models. Economics Letters, 80(1), 123129.

Bailer, S., Bütikofer, S., Hug, S., \& Schulz, T. (2008). Preferences, Party Discipline and Constituency Pressure in Swiss parliamentary Decisions. Mimeo: University of Zurich.

Bawn, K., \& Thies, M. F. (2003). A comparative theory of electoral incentives-presenting the unorganized under pr, plurality and mixed-member electoral systems. Journal of Theoretical Politics, 15(1), 5-32.

Bender, B., \& Lott Jr., J. R. (1996). Legislator voting and shirking: a critical review of the literature. Public Choice, 87(1-2), 67-100.

Benoit, K. (2001). District magnitude, electoral formula, and the number of parties. European Journal of Political Research, 39(2), 203-222.

Besley, T., \& Coate, S. (2008). Issue unbundling via citizens' initiatives. Quarterly Journal of Political Science, 3(4), 379-397.

Blume, L., Müller, J., Voigt, S., \& Wolf, C. (2009). The economic effects of constitutions: replicating and extending Persson and Tabellini. Public Choice, 139(1), 197-225.

Bordignon, M., \& Tabellini, G. (2010), Moderating political extremism: single round vs runoff elections under plurality rule, Review of Economic Studies. Forthcoming.

Braendle, T., \& Stutzer, A. (2010). Public servants in parliament: theory and evidence on its determinants in Germany. Public Choice, 145(1), 223-252. 
Carey, J. M. (2007). Competing principals, political institutions, and party unity in legislative voting. American Journal of Political Science, 51(1), 92-107.

Cox, G. W. (1997). Making votes count: strategic coordination in the world's electoral system. New York: Cambridge University Press.

Cox, G. W. (1990). Centripetal and centrifugal incentives in electoral systems. American Journal of Political Science, 34(4), 903-935.

Crisp, B. F., Escobar-Lemmon, M. C., Jones, B. S., Jones, M. P., \& Taylor-Robinson, M. M. (2004). Voteseeking incentives and legislative representation in six presidential democracies. The Journal of Politics, 66(3), 823-846.

Cronin, T. E. (1989). Direct democracy: the politics of initiative, referendum, and recall. Cambridge: Harvard University Press.

Dow, J. K. (2001). A comparative spatial analysis of majoritarian and proportional elections. Electoral Studies, 20(1), 109-125.

Downs, A. (1957). An economic theory of democracy. New York: Harper.

Duverger, M. (1954). Political parties: their organization and activity in the modern state. New York: Wiley.

Fernandez, C., Ley, E., \& Steel, M. F. (2001). Model uncertainty in cross-country growth regressions. Journal of Applied Econometrics, 16(5), 563-576.

Fossedal, G. A. (2002). Direct democracy in Switzerland. New Brunswick: Transaction.

Frey, B. S. (1994). Direct democracy: politico-economic lessons from Swiss experience. The American Economic Review, 84(2), 338-342.

Gagliarducci, S., Nannicini, T., \& Naticchioni, P. (2008). Electoral rules and politicians' behavior: a micro test, institute for the study of labor (IZA), IZA discussion paper No. 3348.

Gerber, E. R., \& Lewis, J. B. (2004). Beyond the median: voter preferences, district heterogeneity, and political representation. Journal of Political Economy, 112(6), 1364-1383.

Golder, M., \& Stramski, J. (2010). Ideological congruence and electoral institutions. American Journal of Political Science, 54(1), 90-106.

Grossman, G. M., \& Helpman, E. (2005), Party discipline and pork barrel politics, national bureau of economic research, NBER working paper No. 11396.

Hoeting, J. A., Madigan, D., Raftery, A. E., \& Volinsky, C. T. (1999). Bayesian model averaging: a tutorial (with Discussion). Statistical Science, 14(4), 382-417.

Kirchgässner, G., Feld, L. P., \& Savioz, M. R. (1999). Die direkte Demokratie. Modern, erfolgreich, entwicklungs- und exportfähig. Basel: Helbing und Lichtenhahn.

Lancaster, T. D. (1986). Electoral structures and pork barrel politics. International Political Science Review, $7(1), 67-81$.

Lijphart, A. (1990). The political consequences of electoral laws, 1945-1985. The American Political Science Review, 84(2), 481-496.

Lizzeri, A., \& Persico, N. (2001). The provision of public goods under alternative electoral incentives. The American Economic Review, 91(1), 225-239.

Matsusaka, J. G. (1992). Economics of direct legislation. The Quarterly Journal of Economics, 107(2), 541571.

Milesi-Ferretti, G. M., Perotti, R., \& Rostagno, M. (2002). Electoral systems and public spending. The Quarterly Journal of Economics, 117(2), 609-657.

Milligan, K., \& Smart, M. (2005), Regional grants as pork barrel politics, CESifo group Munich, CESifo working paper No. 1453.

Neto, O. A., \& Cox, G. W. (1997). Electoral institutions, cleavage structures, and the number of parties. American Journal of Political Science, 41(1), 149-174.

Ordeshook, P. C., \& Shvetsova, O. V. (1994). Ethnic heterogeneity, district magnitude, and the number of parties. American Journal of Political Science, 38(1), 100-123.

Persson, T., Roland, G., \& Tabellini, G. (2007), Electoral rules and government spending in parliamentary democracies, David K. Levine, Levine's working paper archive No. 321307000000000880.

Persson, T., \& Tabellini, G. (2005). The economic effects of constitutions (Vol. 1). Cambridge: MIT Press.

Persson, T., \& Tabellini, G. (2002). Political economics: explaining economic policy (Vol. 1). Cambridge: MIT Press.

Persson, T., \& Tabellini, G. (1999). The size and scope of government: comparative politics with rational politicians. European Economic Review, 43(4-6), 699-735.

Rae, D. W. (1971). The political consequences of electoral laws. New Haven: Yale University Press.

Raftery, A., Hoeting, J., Volinsky, C., Painter, I., \& Yeung, K. Y. (2009). BMA: Bayesian model averaging, $\mathrm{R}$ package version, 3.10, Available online on http://CRAN.R-project.org/package=BMA.

Raftery, A. E. (1995). Bayesian model selection in social research. Sociological Methodology, 25, 111-163.

Raftery, A. E., Madigan, D., \& Hoeting, J. A. (1997). Bayesian model averaging for linear regression models. Journal of the American Statistical Association, 92(437), 179-191. 
Sala-i-Martin, X., Doppelhofer, G., \& Miller, R. I. (2004). Determinants of long-term growth: a Bayesian averaging of classical estimates (BACE) approach. The American Economic Review, 94(4), 813-835.

Schneider, F., Pommerehne, W. W., \& Frey, B. S. (1981). Politico-economic interdependence in a direct democracy: the case of Switzerland. In D. A. Hibbs \& H. Fassbender (Eds.), Contemporary political economy (pp. 231-248). Amsterdam: North Holland.

Schwarz, H.-R., \& Köckler, N. (2004). Numerische Mathematik. Wiesbaden: Teubner Verlag.

Stadelmann, D., Eichenberger, R., \& Portmann, M. (2010). Parliaments as condorcet juries: quasiexperimental evidence on the representation of majority preferences. Mimeo: University of Fribourg.

Stratmann, T. (1995). Campaign contributions and congressional voting: does the timing of contributions matter? Review of Economics and Statistics, 77(1), 127-136.

Taagepera, R., \& Shugart, M. S. (1989). Seats and votes. The effects and determinants of electoral systems. New Haven \& London: Yale University Press.

Vatter, A. (2003). Legislative party fragmentation in swiss cantons: a function of cleavage structures or electoral institutions? Party Politics, 9(4), 445-461. 